\title{
10. Hierarchy and Precedence in Keiese Origin Myths
}

\section{Timo Kaartinen}

There are two senses in which localized origin is socially significant to people living in the East Indonesian islands of Kei. Each Keiese village society consists of heterogeneous elements which trace their ancestry to places outside their present environment. Traditions of ancestral migration and contact with other island communities indicate a claim to chiefly offices and status, but they occur among common people as well. Apart from the stories of migration, however, there are myths of origin which only concern the origins of the local society itself. In present-day Kei, the origin myths are generally known but rarely subject to public performance. The main difference between the two genres is that whereas traditions of migration focus on the differentiating effects of external relations for the local society, origin myths represent a synthetic perspective on such relationships. Without explicitly stating its implications for the present society, each origin myth in fact indicates a particular order of precedence.

The logic by which precedence is constructed and contested in mythical discourse can only be found out by comparing different myths. I will do this with reference to case material from Kei Besar, an eastern Indonesian island. My purpose is to examine what category relationships define myths of origin as a genre, and how they feature in the social constitution of place as a durable social reality.

I am concerned here with the significance of 'local origin' for validating people's relationships to places and each other. With reference to case material from Kei Besar, an island in eastern Indonesia, I will examine what category relationships define myths of origin as a genre, and how they feature in the social constitution of place as a durable social reality. My general argument is that hierarchy in the communities I have studied is most apparent in the topological definitions of society, whereas the manner in which currently living people trace their relationship to cultural landmarks constitutes a discourse of precedence.

Hierarchy and precedence resemble each other most in their formal criteria of definition. Both involve asymmetric and complementary symbolic oppositions which are applied to social and cosmic relationships. There have been several different approaches at analysing these oppositions in the Pacific and Austronesian context. The theory of hierarchy implies that they are first of all classifications of exchange relationships which constitute the whole of society 
(Barraud 1979; Barraud et al. 1994). Precedence is a privileged relationship to a cosmological origin or source which is constructed from similar symbolic resources as hierarchy and does not presuppose the existence of society as a whole. Instead, the emphasis of an approach which focuses on precedence is on the numerous metaphoric expressions which in Austronesian languages suggest at once organic growth and the process of coming into existence (Fox 1988, 1994).

Generally the two concepts point to different problems and approaches. An exception, however, is the study of cosmology and myth. In origin myths, one finds temporal structures characteristic of precedence, but also the idea that the source hierarchically encompasses all of presently existing society. In the cosmogonic myths of many Pacific societies, social and cosmic relationships appear as a hierarchical unfolding in which the source or beginning is type and the outcome or issue is token of the same, ontologically basic categories (Sahlins 1985:14; Valeri 1985; Siikala 1991:54).

I will not attempt a comprehensive review of these concepts and approaches, but explore them in the hope of finding out elements in them that best apply to the problems I am trying to address in studying historical traditions and genres in the Kei Islands. My focus in this paper will be on myths of origin called tum, probably the best documented folkloric genre in the Kei Islands. A number of these myths were published by Hein Geurtjens (1924), a Dutch Catholic missionary who collected them between 1900-1920, during the first years of actual colonial presence in Kei. Through Geurtjens' book, the myths were also an influential source for F.A.E. van Wouden's (1968) perspective about society and cosmos in eastern Indonesia.

Tum in Keiese means 'basis' or 'origin' and has a connotation of organic growth, as is indicated by its cognate words from many other Austronesian languages (Fox 1988:14). The name of the genre indicates that the stories are regarded as fundamental to the existence of society. The problem is, what society? How can we account for the effects of the myth in constituting it? If we begin to look at myth as a reflection of observable social life, we end up reducing its meaning to particular contexts and fail to account for the structuring power of its symbolism either in terms of hierarchy or precedence.

This problem, however, does not have to arise if myth is regarded as an integral part of social life. Jukka Siikala suggests that in order to take myths 'seriously' one must consider both their 'internal' and 'external' continuity. The internal continuity or 'plot' of the text, and the external continuity of such texts as a socially significant tradition together define myth as historical, which in turn justifies the study of myth in order to say something about society in general (Siikala 1991:4). 
In my examination of tum, I will begin from their general, social context and suggest where in terms of social relationships and institutions these myths could be 'located' in Keiese society. I will then compare two particular myths and show that they represent opposed perspectives on society and the world. The hierarchical implications of these myths likewise have a definite place in society. 'Society as a whole' in this case is topological. Certain places are the foci of ontologically fundamental relationships to people who live in the social milieu defined by them. The final problem is how these milieux and relationships are related to the general context of social life: is it justified to speak about categorical encompassment as more than a contextual phenomenon?

\section{People of the Mountain, People of the Cape}

Kei, located some $500 \mathrm{~km}$ from Ambon in Southeast Maluku, is divided into two groups of islands. Small Kei, the western part of the group, consists of flat coral islands, while Great Kei, the eastern part, is dominated by one long island, essentially one mountain range which rises from the sea. The village of Banda Eli where I stayed during my fieldwork in 1994-96 lies in the northern part of Great Kei. Unlike the surrounding villages which tend to be divided into Islamic, Protestant and Catholic sections, Banda Eli is wholly Islamic. Its inhabitants also speak a different language from Keiese, and a majority of them claim ancestry in the Banda Islands at the time before the original Bandanese found refuge from Dutch colonization in Kei.

Despite their linguistic and ethnic difference from the Keiese, people of Banda Eli are very much part of Keiese society. Pure Bandanese ancestry is regarded as a criterion of chiefly status in the village, whereas the commoners are said to have at least some Keiese ancestors. The position of chiefs is explained largely in the same manner as in the surrounding Keiese villages. When the village was founded, chiefs established a privileged relationship to land through various kinds of alliance with previous land-owners, and later gave protection to other settlers who became their dependants. Past connections with the Keiese are, in other words, fundamental to their authority. Even though predominantly immigrant chiefs constantly make reference to origins outside the Kei Islands, their precedence within the local community depends on their connection to the autochthonous past.

I say precedence because there is by no means any consensus about chiefly authority and the chiefs' relationship to autochthonous Keiese society. Banda Eli is founded on land identified with several 'villages of origin,' each with its own stories and landmarks. The idea of these villages and of autochthonous society in Kei generally is in radical contrast with the present idea of society. Autochthonous Keiese are said to have lived in an undifferentiated community, either dwelling in a single big house or in a cave, with no institution of marriage and no knowledge of cooking (Geurtjens 1924:241, 277). Social differentiation 
and marriage were brought to them by immigrants who also became the rulers and chiefly class of the islands (Geurtjens 1921:179). A prominent symbol of the deified principle of 'law' brought by the immigrants is hawear, a sign of prohibition made of white coconut leaf. The leaf indicates that the entity - a woman, a garden, or a piece of land — which it protects is inviolable; in Keiese eyes, it signifies the value of that entity.

Representations of Keiese society as a whole have often focused on the division between people of different status, known as mel-mel ('chiefs'), ren-ren ('commoners'), and iri-iri ('slaves') (Geurtjens 1921:179; Klerks 1939). However, the categories of ren-ren and iri-iri can only be understood in their respective relationship to mel-mel (Barraud 1979:120). The opposition of chiefs and commoners is associated with the dualism of autochthonous and immigrant people through topological metaphors such as mel tum lair, ren wuar tel: 'mel originate from the cape, ren from three mountains'. Commoners are also associated with immobility, chiefs with mobility and action. The Keiese words for cape and mountain occur in local place names which define the community as something composed of autochthonous and immigrant elements, but do not identify these components with any social groups.

The status of 'slaves', on the other hand, is related to ideas about morality and personal value. The ancestors of slaves are said to have trespassed against the moral order, known as the law of Larwul Ngabal. This law was brought to Kei by the ancestors of the chiefly class and is under the guardianship of local rulers (rat) whose domains in Kei consist of up to a dozen villages each. The influence of state administration and trade have strengthened the position of chiefly groups over the last one hundred years and sustained an interpretation of status by which kings and chiefs are all identified with mel-mel who then rule all different levels of community, segmented into individual domains (ratschap), villages, hamlets, and clans.

It is possible to argue that the two relationships of mel-mel to other people and the two levels of community ruled by ordinary chiefs and the kings constitute levels in a comprehensive social ideology. What easily remains understated in such a model, however, is the capacity of local communities to reproduce these levels in other institutions and in more limited social settings. In northern Great Kei, ritual exchanges between local and external forces are not confined within a single village, but take place within the framework of dyadic alliances between Houses of different villages. Such alliances which may be conceptualized in several ways are often strikingly intimate in nature. The parties barter foodstuffs and make gardens together. They participate in each others' healing rituals and family feasts. The Keiese concept of rahantaran ('stopover house') which applies to many such relationships in Banda Eli suggests that people in one House issue from the other House. They may have been 
concretely recruited from the 'donor' House, but in other cases their birth is said to have been the result of its fertility magic.

Rahantaran is not the only relationship between Houses which is of relevance here. There are many stories in which immigrant Bandanese help a Keiese family in a war against another Keiese party and receive land in reward. Other alliances result from the settlement of a feud which results from an elopement between the subordinate people of two Houses. I will not attempt a systematic analysis of these relationships here, but want to point out their significance as a context for cosmological ideas. Each House has a network of relationships with other Houses in distant parts of Kei, and by virtue of these relationships they become part of intense disputes and fights which arise from the symbolic connection between land rights and honour. In each case, general categories which define personal value and origin become salient as people, to use an indigenous phrase, 'become aware' of durable social attachments.

Alliances and networks of this kind extend so widely in space that it would be difficult to call them constituting elements of society if people were not constantly reminded of them by well-known landmarks. Tuburlai, a cove in the northern end of Banda Eli, is known as the place where Larwul Ngabal, the immigrant principle of justice, 'first landed' in the vicinity, and was received by people who lived on top of a steep cliff next to the cove.

Such places are often recognized as pomali or 'taboo' by people who live near them. On the other hand, not everyone in the respective communities participates in rituals which focus on the sites. A single village may have several cosmological sources, each with a mythological account of its own. Ritual exchanges between immigrant and autochthonous parties which take place in these places maintain the sense of myth as part of social reality; the sites, in turn, would not remain potent if people were not reminded of their importance by myths (Siikala 1991:3).

\section{Ideas of Autochthonous World}

The two myths I will examine below were collected in an atmosphere of rivalry between persons who both aspired to headmanship in a village north of Banda Eli. They were in fact close relatives, but belonged to Houses with entirely different kinds of claims to land and people in their village. The occasion which prompted the telling of the myth in each case was talk about the relationship between a chiefly and a commoner House. This is a synopsis of the first myth:

When the world began, an old man and woman were living alone at the shore. The man set a fish-trap and repeatedly caught two nabi laut, pieces of driftwood which he eventually brought back to his house. When the old couple went to their garden in the morning, the logs changed into two little boys who cooked food for the man and the woman. The man and the woman caught them and decided to bring them up as their 
children. When the boys were grown up, the elder of them asked the old man to make a bow and arrows. He got them and shot an arrow at the mountain. A flower was planted at the house: it would wither if he died. He followed the arrow and found a princess (putri) who lived in a fortress in the interior of the island. He married the princess and stayed in her house for a week. Then he shot another arrow towards the cave of a suangi, a demon living in the cave of Fotun Kub. Another flower was planted at the princess's house to show if he was dead or alive. Despite the warnings of the princess, the boy went on to retrieve the arrow and was devoured by the demon. The flowers withered.

Thus the younger brother who had stayed in the village knew that his elder brother was in trouble. He went to look for him and shot another arrow towards the mountain. By following the arrow, he first found the princess, then the demon. He killed the demon and rescued his brother from its belly. They returned to the princess who was the elder brother's wife. The land and the slaves of the princess were divided between the two brothers: the younger went and ruled over the land and sea to the west of the mountain; the elder ruled over the land and sea to the east (the land which includes part of Banda Eli). The elder brother's grandson finally descended to the shore and was integrated into a coastal village by means of exchange of land with a House already living at the coast.

The old couple who live at the seashore represent the autochthonous people, but they are clearly incapable of reproducing themselves. Miraculously they get two 'sons' who drift into their midst and only become human after they have been brought into the house. A related motif in other Keiese myths is the transformation of a sea-snail or frog into a nobleman after it has been cooked by an old woman (for example, Geurtjens 1924:215, 257, 263). Each motif exemplifies a Keiese cosmological pattern: before the immigrant male has been incorporated in society, he lacks the capacity to move autonomously and approaches the island and the woman in it like flotsam (Barraud 1990:206).

Active agency is consistently represented by the two male heroes, but such agency only appears after they have been brought up by the old couple. Thus the boys are not incorporated into island society by marriage, but by receiving food; even their maleness can be seen as a local product. The fertile aspect of autochthony is represented as a princess who lives on the mountain. When the heroes are ready to face her, they do so in a very masculine way, by penetrating it with arrows. It is here that the myth introduces the categories of elder and younger brother and constructs a relationship between east and west coast in terms of their precedence. The elder goes first, stays with the princess and has intercourse with her for a week, but later gets eaten by the demon. The younger brother goes after him, abstains from sex with the princess, succeeds in killing 
the demon, and rescues his brother. The stage is set for a diarchic arrangement which reflects the two aspects of the 'stranger king' (Sahlins 1985:91). But instead of playing out this opposition, the brothers part: the younger becomes chief of the western and the elder of the eastern side of the island.

In this way, Keiese myths speak about relationships between places rather than identifiable people. In the context in which I was told this story, it only points to hierarchical relations which focus on a single chiefly House, and never mentions its rivals. The second myth describes the relations of the rival House to subordinate people and land:

A man called Terngun lived at the coast. One day a gust of wind knocked over the coconut milk which his daughter had prepared to wash her hair. The hero decided to declare war against the northern wind. On his way to the village of the wind, he encountered a water-fowl, a sea-cucumber, and an octopus who joined in and helped him. The war was a test of whether the wind could knock over the hero's boat. With the help of the sea-animals, the hero managed to stay immobile in the water and then proceeded to destroy the village of his adversary. Defeated, the northern wind gave the hero two golden objects which he brought back to his village.

The second myth is in direct contrast with the first in that the male hero is a warrior from the beginning and moves outwards rather than inwards relative to the island. His adversary, the male outsider, is not recognized as a human being but as a tempest. However, the incoming wind causes uncontrolled movement by spilling the coconut milk which significantly resembles the uncontrolled, inward movement of the two drifting logs in the first myth.

The motif of the wind which symbolically rapes the girl and that of the contest against the wind are also found in other Keiese myths, with similar consequences for the plot (Geurtjens 1924:269). The hero takes revenge from the outsider by winning a contest in which he has to control his movement and stay immobile in the sea.

The contrast between the two myths concerns (1) the initial value of male agency, and (2) the domain in which this agency operates. In the first myth, the male hero loses his battle after encountering the autochthonous female; however, the order of seniority and the order of events in the narrative indicate that fertility is established as the encompassing value in this encounter. In the second myth, the hero who goes to fight out at sea brings home valuable metal objects as ransom. Had he not been given them, it can be expected that he would have brought back the dead enemy instead. The valuables represent the outcome of heroic male action and a replacement of the powers of autonomous reproduction inherent in the girl. Each myth thus celebrates a different aspect of the 
autochtonous society: its fertility and its capacity to interact with outsiders. A crucial difference between the myths is suggested by the different condition (dead versus alive) in which the outsider is incorporated into society. In the first myth, male heroics are encompassed by autochthonous fertility; in the second myth, fertility is just a starting point in the interaction between the self and the other which eventually transforms the notion of value within society itself.

As Barraud (1990:207) suggests, the inversion of movement in the two stories coincides with an inversion of values. Valuable human beings arrive from the sea in the first myth and establish society as a complementarity between the masculine and feminine. Seen against the background of the Keiese institution of bridal payments, the valuable things which are brought in from the sea in the second myth enable autochthonous society to maintain its reproductive autonomy by introducing exchange within its own boundaries.

Ethnography of other Maluku societies contains various instances of cosmology and mythology in which two antagonistic perspectives can ultimately be seen to complement and implicate each other. One example are 'myths of life and image', two kinds of accounts of the origin of the state, in Halmahera (Platenkamp 1988). In Kei, an active, violent attitude directed towards the outside world is opposed to an attitude of ritually controlled, pacific interaction between society and external forces (Barraud 1979:65). A comparable opposition between cosmological perspectives is associated with the classification of local societies into groups called siwa and lima in the Central Maluku. Here lima, the division of society in 'five', is associated with the idea of transformative male action and control of the external world as superior value, while societies called siwa ('nine') value fertility and the complementary relationship between male agency and female powers (Valeri 1989:133).

\section{Cosmology in Society}

Comparison of the myths I have outlined with other Keiese myths and to similar cases elsewhere in Maluku suggests that Keiese cosmological thought does involve 'levels of value'. Each conceptualization of how the community relates to the external world is confronted by an opposite hierarchical evaluation, making the two perspectives inseparable (ibid.:137). Transposed to presently existing society, however, the common reference of the myths is far more difficult to see. Each of the stories makes reference to an entirely different set of people and places known by name, but does not have anything to say about the elements of society or the landscape which are the subject of the other myth. The relationships they do address concern individual Houses, not presently existing communities in their entirety.

The application of hierarchy in this case would presuppose that certain cultural values which are perceived as universal are instantiated in concrete 
social relationships which not only constitute a discursive or performative context for those values but are 'decisively oriented' by them (Dumont 1980:37). I have suggested previously that, rather than looking at presently existing divisions between villages and other entities, one should be looking for such context in alliances between Houses which mediate each others' relationship with autochthonous and foreign powers.

The profound significance of such an alliance became clear to me through events which occurred towards the end of my fieldwork. A man was gravely ill, and his family summoned a woman from another House to help find the cause of his sickness. The woman's House stood in a peculiar relationship of alliance to the House of the sick man: when its male line had become extinct after a feud generations ago, new men had been recruited to it from the allied House. The relationship between these Houses thus follows a general pattern of complementarity between the autochthonous and the immigrant: while autochthonous people depend on the immigrants for men in order to reproduce themselves, the immigrants need autochthonous people to mediate their relationship to local spirits (cf. Barraud 1990:205).

The affliction of the man was construed as a potential effect of a marriage between persons from different generations. This rule is an essential part of what people in northern Great Kei include in the concept of autochthonous 'law' which was later replaced by a new law known as Larwul Ngabal brought by immigrants. Autochthonous society is still present in the form of spirits known as the 'disappeared' which punish immoral conduct through possession, illness or death. Geurtjens (1924:ii) tells that origin myths used to be told only at night because in the daytime they might summon the spirits who might take some of the living with them. Their punishment is said to be more violent and 'severe' than that dictated by Larwul Ngabal. In order to escape the punishment of the 'disappeared', the entire family of the afflicted person has to make an offering at the site where Larwul Ngabal first landed on the island.

The offering to the autochthonous spirits thus repeats a founding event of society, the arrival of the immigrants whose law replaces the old one. In general terms, the singular image of Larwul Ngabal, compared to the plurality of autochthonous spirits, indicates that the local society is encompassed by external principles. In this context, however, the 'doing of justice' clearly consists of tribute by external powers to the autochthonous ones. The ritual offering (an old coin) is said to replace the body of the person who would otherwise have to be offered as a human sacrifice. Such replacement, Barraud et al. (1994:15) argue, implies the subordination of one party to another, in this case, of immigrants to the autochthonous party.

The guardian of Larwul Ngabal is a ruler called rat whose domain covers a dozen villages in northern Great Kei. In an abstract sense, this domain represents 
an encompassing socio-political level in Keiese conceptualizations of society (Barraud 1979:62). At least in northern Great Kei, however, the relationship of local communities with the domain can be constructed in several ways. The first myth cited above defines the eastern shore as the domain of the 'elder brother' and the western shore as the domain of the 'younger brother'. Relative to this, the ruler's path represents a categorical inversion, since he first settled at a village on the western coast before moving to his current seat on the eastern coast. In the second myth, the external world provides local society with valuables which replace the dead enemy. The ruler, in turn, is said to have settled in Great Kei because his sister, an immigrant woman, married an autochthonous man.

In this way, Fox (1994:99) argues, precedence allows people to change the relative emphasis of such oppositions as elder/younger or male/female, and sometimes reverse their order of value and trace their relationship to the mythical source or origin in multiple ways. Precedence so conceived does not conflict with the existence of a hierarchy of values; my point is, however, that the institutional order oriented by it is open to various overlapping definitions.

\section{The Seriousness of Myth}

The structures of precedence associated with the contemporary social order of villages and domains indicate that the category relationships which emerge in the myth are also broadly used in the discourses which order Keiese society as a whole. Origin myths called tum, however, are clearly not charters of this order. As we have seen, mythical categories are applicable to Keiese society in general, but often have a specific connection to a place. Two theoretical perspectives open up from these observations: myths can be seen either as shared cultural resources, or as discursive knowledge with conditions of truth and validity defined by the spatial and social context.

The first approach appears better founded in light of the fact that the connection of the myth to a particular landmark or place is not an essential feature of the genre as a whole. Commentaries which Geurtjens (1924) added to the myths he collected often suggest that the plausibility of mythical events in indigenous eyes derives from the familiar circumstances in which they take place. This would support the view that the 'root paradigms' of a culture, assumptions about what motivates action for various kinds of agents (men, women, chiefs, witches, exchange partners, and so on) and ideas about the risks and supernatural forces which affect people in different milieux (forest, village, sea, and so on) are reflected in and reinforced by textual models (Turner 1981:150).

Unfortunately, such perspective leaves unanswered the question which arises from what is specific and theoretically interesting in the symbolic resources and 
patterns of the myths. If origin myths are in some sense the 'basis' or 'origin' of some aspects of present-day society, as their generic name indicates, what is this society, and how do myths constitute it? The consideration of the social context of myths has already suggested that the answer might be found by looking more closely at the connection of certain myths to a place. In his collection of forty Keiese stories, Geurtjens (1924) sets aside what he calls 'patriotic' stories, while others are just stories. Stories of the former kind are held to be true by particular communities, but included in the same genre as ordinary tales. Fox (1979:16-19) describes a similar difference between ordinary tales and 'true tales' in Roti: the truth of the story ultimately depends on whether or not it refers to the royal genealogy of the domain where it is told. The domains and places to which the stories are connected might be seen as discursive spaces in which a specific sense of reality and truth determines the constitutive power or 'seriousness' of the myth.

The idea of myth as 'discourse' implies that speaking about the past is constrained by conventions and norms which reflect and constitute order. Lamont Lindstrom (1990:25) has applied such an approach to the Polynesian Tanna culture by defining it in terms of procedures and controls which regulate the distribution of knowledge. These procedures make certain kinds of knowledge 'serious' by 'divor[cing] it from the local everyday background' and organizing it into 'doctrines' and 'disciplines' (ibid.:28, 30).

The difficulty of treating Keiese origin myths as discourse in this sense is that there are no well-defined conditions of truth, seriousness and textual authority which would correspond to Lindstrom's description. Keiese tum do not constitute an object of firm belief, nor is their truth a matter of doctrine or coherent theory. Neither do they constitute society as an ordered whole. After watching Keiese people who made arguments about land rights by narrating tum, Geurtjens (1924:iii) observed with amazement that nobody ever contradicted the facts in another person's story. Instead, he would just tell another story which, on the surface, bore no relationship to the previous one. Instead of making truth claims, as discourse does, in a generalizing cognitive framework, mythical thought 'comes to rest in the immediate experience' (Cassirer 1953:32), drawing the limits of things and providing internal organization for human activity as a precondition for any discursive awareness of foundational events.

Myths speak to each other at the level of Keiese cosmological notions, but each of them affirms a singular event or place as the origin of society. These events and places do not define presently existing communities, but ancient ones. Likewise, the alliances through which individual Houses are connected across village and status boundaries thus have little to do with society as an organized whole. They arise from sociality which alternates between a recognition and non-recognition of the external world. This sociality differs from present-day 
social order in that it requires the periodic restoration of society in its autochthonous undifferentiated state (cf. Spyer 1996:31). The possibility of such non-recognition of the external world is conceivable in the smallest societies, even those seemingly too small to sustain autonomous social life, as Valeri (1994:202) argues in reference to the way in which the Huaulu of Seram seek to encompass the complexities of their historical environment.

People of different status have a different relationship to autochthony. The status of chiefs or mel-mel is defined by their immigrant origin to the extent that by admitting marriages between their ancestors and autochthonous Keiese, they would forfeit their superior status. For this reason, chiefly narrators make a difference between the origin of the Houses which they occupy and their personal origin outside Kei. In their accounts, the autochthonous founders of a land-owning house have become extinct, and new people have been recruited from an immigrant chiefly house sometimes several times over. Not a trace of personal relationship is acknowledged to remain between the founders of a House and its present occupants. Commoners, by contrast, are often able to work out an unbroken genealogical chain between mythical origins and the present.

Interestingly, genealogical accounts going back to the beginning of the world are always about 14 generations long. The uniformity of this time-frame is in itself remarkable: it demonstrates that there is a broader, genealogical discourse about the personal origin of different people outside Kei, and about their value and honour as persons. Unlike mythical accounts about the origin of places and Houses, genealogical accounts can be debated and contested. The character of these two genres as discourses of value in society therefore depends on the way in which they establish a connection between the ancestral past and the present.

Narrative has different ways and modes of creating such connectedness between different chronotopes which, as defined by Mikhail Bakhtin, exist both in texts and in the consciousness of people who read or listen to them (1981:84). As the name of the genre suggests, the primary chronotope of tum is the understanding of mythical events as precedents. In terms of the 'internal' continuity of the myth, this means that later events repeat (and sometimes invert) the pattern of earlier ones. Through ritual, past and present are connected through space rather than through time (Valeri 1990:72). 'Externally' myths extend their meaning to the present through such institutions as local House alliances, the ruler and his domain, or daily interaction between chiefs and commoners in the village context. Mythological schemes alone do not constitute these institutions and contexts as a hierarchical order. However, an interest in creating such orders is evident whenever a society affirms its own totality against external, differentiating facts, pitting its myths against other myths with no more than implicit recognition of its constant dialogue with social others. 


\section{References}

Bakhtin, Mikhail

1981 The dialogic imagination. Austin: University of Texas Press.

Barraud, Cécile

1979 Tanêbar-Evav: une société de maisons tournée vers le large. Cambridge: Cambridge University Press/Paris: Editions de la Maison des Sciences de l'Homme.

1990 Wife-givers as ancestors and ultimate values in the Kei Islands. Bijdragen tot de Taal-, Land-en Volkenkunde 190(2-3):193-225.

Barraud, C., D. de Coppet, A. Iteanu and R. Jamous

1994 Of relations and the dead: four societies viewed from the angle of their exchanges. Oxford: Berg Publishers.

Cassirer, Ernst

1953 Language and myth. New York: Dover Publications

Dumont, Louis

1980 Homo hierarchicus: the caste system and its implications. (2nd edn) Chicago: The University of Chicago Press.

Fox, James J.

1979 Standing in time and place: the structure of Rotinese historical narratives. In A. Reid and D. Marr (eds), Perceptions of the past in Southeast Asia, pp.10-25. Singapore: Heinemann Educational Books (Asia) Ltd.

1988 Origin, descent and precedence in the study of Austronesian societies. Public lecture in connection with De Wisselleerstoel Indonesische Studiën, 17 March 1988, Leiden.

1994 Reflections on 'hierarchy' and 'precedence'. In M. Jolly and M. Mosko (eds), Transformations of hierarchy: structure, history and horizon in the Austronesian world. History and Anthropology (Special Issue) 7:87-108.

Geurtjens, H.

1921 Uit een vreemde wereld of het leven en streven der inlanders op de Kei-Eilanden. 's-Hertogenbosch: Teulings.

1924 Keieesche Legenden. Verhandelingen van het Koninklijk Bataviaasch Genootschap van Kunsten en Wetenschappen 65(1). Weltevreden: A. Emmink and The Hague: M. Nijhoff.

Klerks, Jos

1939 Gegevens over Keieesche huwelijksadat. Bijdragen tot de Taal-, Land- en Volkenkunde 98(3):285-323. 
Precedence

Lindstrom, Lamont

1990 Knowledge and power in a South Pacific society. Washington DC: Smithsonian Institution Press.

Platenkamp, Jos

1988 Myths of life and image in Northern Halmahera. In D. Moyer and H. Claessen (eds), Time past, time present, time future, pp.148-167. Verhandelingen van het Koninklijk Instituut voor Taal-, Land- en Volkenkunde 131. Dordrecht: Foris Publications.

Sahlins, Marshall

1985 Islands of history. Chicago: University of Chicago Press.

Siikala, Jukka

1991 Akatokamanava: myth, history, and society in the Southern Cook Islands. Auckland: The Polynesian Society in association with the Finnish Anthropological Society, Helsinki.

Spyer, Patricia

1996 Diversity with a difference: adat and the New Order in Aru (Eastern Indonesia). Cultural Anthropology 11(1):25-50.

Turner, Victor

1981 Social dramas and stories about them. In W.J.T. Mitchell (ed.), On narrative, pp.137-164. Chicago: University of Chicago Press.

Valeri, Valerio

1985 Kingship and sacrifice: ritual and society in ancient Hawaii. Chicago: University of Chicago Press.

1989 Reciprocal centers: the Siwa-Lima system in Central Moluccas. In David Maybury-Lewis and Uri Almagor (eds), The attraction of opposites: thought and society in the dualistic mode, pp.117-141. Ann Arbor: The University of Michigan Press.

1990 Diarchy and history in Hawaii and Tonga. In Jukka Siikala (ed.), Culture and history in the Pacific, pp.45-79. Transactions 27. Helsinki: Finnish Anthropological Society.

1994 'Our ancestors spoke little': knowledge and social forms in Huaulu. In Leontine Visser (ed.), Halmahera and beyond: social science research in the Moluccas, pp.195-212. Leiden: Koninklijk Instituut voor Taal-, Landen Volkenkunde Press. 
Wouden, F.A.E., van

1968 Types of social structure in eastern Indonesia. Koninklijk Instituut voor de Taal-, Land- en Volkenkunde, Translation Series 11. Transl. Rodney Needham [Preface by G.W. Locher]. The Hague: Martinus Nijhoff. 